Chapter 7

\title{
Trends in Research and Technology Development Related to Zoonosis Control Based on Bibliometric and Patent Analyses-Taking Rabies as an Example
}

\author{
Hiromi Takahashi-Omoe and Katsuhiko Omoe \\ Additional information is available at the end of the chapter \\ http://dx.doi.org/10.5772/57566
}

\section{Introduction}

Infectious diseases, particularly zoonoses, are recognized as the sources of serious problems that affect public and animal health around the world. Emerging infectious diseases have been reported at an unprecedented rate since the 1970s and a large proportion of these diseases are considered to be zoonoses [1]. However, reemerging zoonoses are also affecting public health around the world, in particular rabies, a classic zoonosis that is problematic in Africa and Asia, while new outbreaks have occurred in areas that were previously free of this disease, such as the islands of Flores and Bali in Indonesia [2].

Thus, research and technology development have been promoted for controlling emerging and reemerging zoonoses in developed countries. In the case of rabies, the research and technology developed to prevent this disease has been advancing. Rabies is a vaccinepreventable disease, so a vaccine has been developed. The type of vaccine produced using animal nervous tissues has been progressively replaced by safer and more immunogenic vaccines, which are purified from cell culture supernatants. In addition, new replicative vaccines have been developed for the oral vaccination of wildlife, which are either attenuated rabies vaccines or recombinant vaccines where different viruses express the rabies glycoprotein [3]. Moreover, user-friendly diagnostic methods have been developed, e.g., a rapid immunochromatographic test kit and a simple enzyme-linked immunosorbent assay (ELISA) $[4,5]$. Understanding the current trends in research and technology development related to rabies control may provide a useful reference regarding the technological needs encountered in the field of zoonoses. 
Bibliometric analysis is considered to be an effective method for identifying research trends in infectious disease control. Quantitative surveys of research articles (hereafter referred to as article) based on bibliometric studies have been reported in the field of infectious diseases, such as human immunodeficiency virus (HIV)/acquired immune deficiency syndrome (AIDS) [6], tuberculosis research in India and China [7], and various forms of infectious disease research in different regions of the world [8], Asia [9], and around the world [10]. In particular, we have surveyed Asian and worldwide research trends, while ensuring that we avoided underestimating the number of articles in non-English and regional journals, rather than simply surveying journals registered in the "Infectious Disease Category" of the Science Citation Index Expanded ${ }^{\mathrm{TM}}[9,10]$.

Patent analysis is also considered to be an effective method for technology development trend analysis. Patents are examined and granted by patent offices, and they are considered to be objective indicators of technology development activities. In addition, patents have significant advantages in terms of database availability, the variety of information included, and their systematic classification according to standardized schemes, e.g., the international patent classification (IPC) supports the detailed analysis of specific technological aspects. For these reasons, patent data are used intensively for strategic technology management by companies [11], as well as for science and technology (S\&T) measurement in policy-making processes and academic research in various fields [12]. Indeed, patent analyses have been reported in the field of infectious diseases, such as hepatitis B vaccines [13] and influenza [14,15].

Research and technology development for rabies control is considered to be important for future public and animal health throughout the world, as described above. However, to the best of our knowledge, bibliometric and patent analyses of rabies have not been reported yet. Therefore, in this chapter, we report the current trends in research and technology development for rabies control in the US, the EU, and Asia based on analyses of articles and patent applications. We targeted patent applications because publication of a patent application is invariably the earliest point when relevant technology information becomes available to the public because it is the first set of detailed and up-to-date published information. Furthermore, the number of patent applications in particular technological areas is considered to indicate the volume of resources allocated [16].

The trends in research and technology development for rabies control will be summarized using the following indicators.

- Number of articles and patent applications during each year and by each country

- Number of authors and applicants by nationality

- Number of articles by organization

- Major research areas of articles and the technical areas of patent applications

- Top 10 cited articles and patent applications

Based on this analysis, we discuss the future directions of research and technology development for rabies control. Moreover, we propose the development of a survey method for zoonosis control, research and technology development. 


\section{Trends in rabies research based on articles}

We used a two-tiered approach to analyze research related to rabies control. First, we performed a quantitative analysis of all articles about rabies. Subsequently, we analyzed the top 10 cited articles, irrespective of whether they were related to rabies control.

\subsection{Method of analysis}

The Web of Science ${ }^{\circledR}$ [17] was used to survey articles about rabies, which covers over 12,000 journals worldwide, including open access journals. Using the Web of Science ${ }^{\circledR}$, keyword and title search of articles was performed using the terms "Rabies" OR "Lyssa" (to include virus species related to rabies virus) NOT "Rabi" (to exclude articles in the field of optics, e.g., articles related to "Rabi oscillations") on June 24, 2013. The publication period of articles ranged from January 1, 2001 to December 31, 2011.

We focused on articles and excluded reviews, proceedings papers, and other types of publications. This is because articles are high quality because they have been peer reviewed and are directly linked to the outputs of the latest research.

Other articles in the field of infectious diseases retrieved by the Web of Science ${ }^{\circledR}$ were also analyzed to identify the characteristics of articles related to rabies.

\subsection{Leading countries based on the number of articles}

The total number of articles related to rabies published throughout the world during 20012011 was 2,565. We regrouped the articles by country to identify any possible differences in research output among countries. The US was the leading country, with the highest percentage of total articles, i.e., $32.5 \%$ of the total ( 833 articles). There was a big gap for the second placed country, France, with $10.6 \%$ of the total (273 articles). The UK, Brazil, and Germany followed with $10.1 \%$ (258 articles), 8.6\% (220 articles), and 7.2\% (185 articles), respectively (Figure 1).

As shown in Table 1, the US, France, the UK, and Germany were the top four countries with most articles related to rabies, and they were also the leading countries for all articles about infectious diseases. However, Brazil ranked in the top five with most articles related to rabies. This showed that rabies research was a particular focus in Brazil.

\subsection{Annual changes in the number of articles}

As shown in Figure 2, the total number of articles related to rabies increased during 2001-2011. However, the US did not show a remarkable change, although it produced the highest output. Other countries such as the UK, France, Brazil, and Germany also had stable outputs. Thus, the overall increase in articles was considered to be attributable to other countries that were not surveyed in this study. 


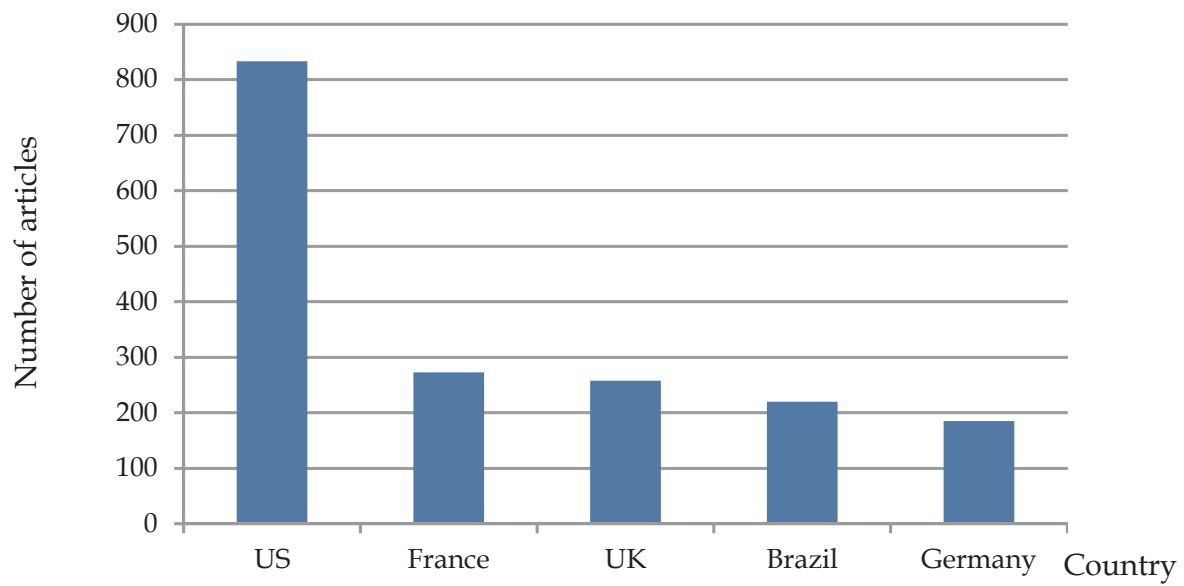

Figure 1. Number of articles related to rabies by country during 2001-2011

Number of articles about rabies

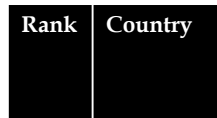

\begin{tabular}{|l|}
\hline $\begin{array}{l}\text { Number of } \\
\text { articles }\end{array}$ \\
\hline
\end{tabular}

Relative to

the total

number of

articles (\%)

\begin{tabular}{|c|c|c|c|}
\hline 1 & US & 833 & 32.5 \\
\hline 2 & France & 273 & 10.6 \\
\hline 3 & UK & 258 & 10.1 \\
\hline 4 & Brazil & 220 & 8.6 \\
\hline 5 & Germany & 185 & 7.2 \\
\hline
\end{tabular}

Search condition

Keywords: Rabies OR Lyssa NOT Rabi

Document type: Article

Total number of articles: 2,565 articles
Number of articles in the field of infectious diseases

\begin{tabular}{|c|c|r|r|}
\hline Rank & Country & \multicolumn{1}{|l|}{$\begin{array}{l}\text { Number of } \\
\text { articles }\end{array}$} & $\begin{array}{l}\text { Relative to } \\
\text { the total } \\
\text { number of } \\
\text { articles (\%) }\end{array}$ \\
\hline 1 & US & 35,488 & 38.5 \\
\hline 2 & UK & 9,437 & 10.2 \\
\hline 3 & France & 7,625 & 8.3 \\
\hline 4 & Germany & 4,908 & 5.3 \\
\hline 5 & Spain & 4,906 & 5.3 \\
\hline
\end{tabular}

Search condition

Research field: infectious diseases

Document type: Article

Total number of articles: 92,113 articles

Table 1. Comparison of the rankings for articles related to rabies and all infectious disease articles during 2001-2011

\subsection{Number of articles by organization}

US Centers for Disease Control and Prevention (US CDC) published most articles related to rabies (198 articles) during 2001-2011. Institut Pasteur (France) and Thomas Jefferson University (US) published the second and third highest numbers of articles (141 and 87 articles, respectively) (Figure 3). 


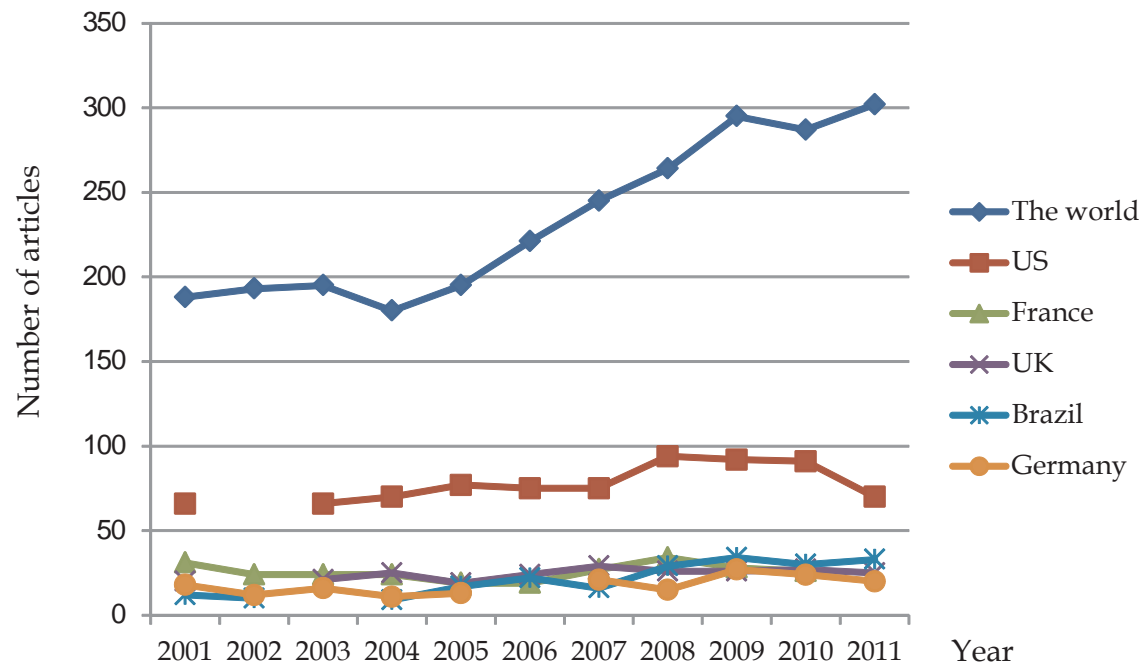

Figure 2. Number of articles related to rabies by year during 2001-2011

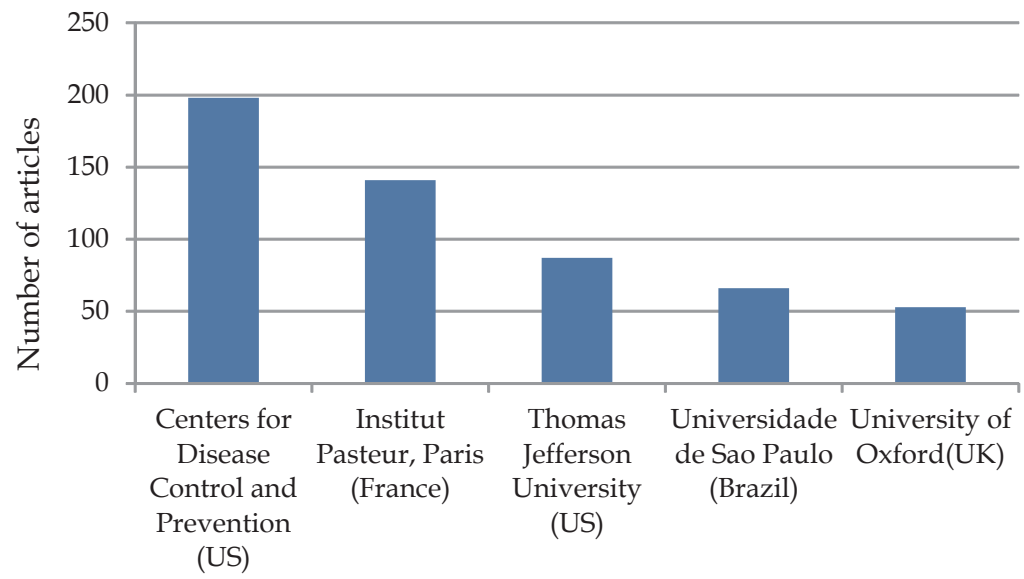

Organization

Figure 3. Number of articles related to rabies by organization during 2001-2011

\subsection{Major research areas}

Figure 4 shows the number of articles related to rabies for each research field, which showed that the main field of rabies research was veterinary sciences. Research was also conducted in 
basic sciences, such as virology and immunology. It is considered that virological and immunological research on rabies contributes to the development of vaccines and diagnostic methods.

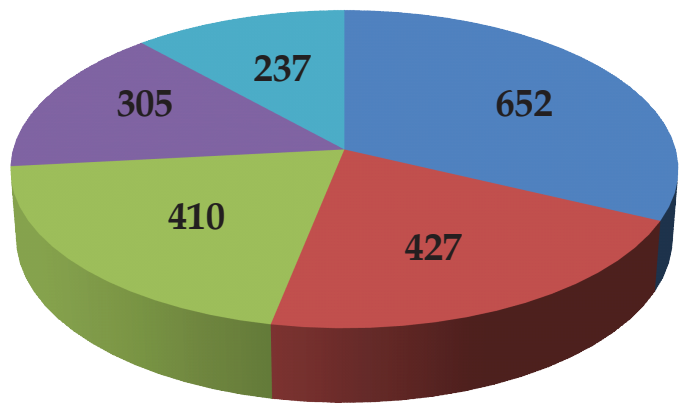

Veterinary sciences

- Virology

- Immunology

Infectious diseases

research experimental medicine

The values are the number of articles.

Figure 4. Number of articles related to rabies by research field during 2001-2011

\subsection{Top 10 cited articles}

Table 2 shows top 10 most cited articles related to rabies. Of these articles, two reported and discussed methods for rabies control $[18,19]$. It was interesting that the two articles were based on new research areas, i.e., agent-based modeling and economic analysis. These studies were not categorized in the major research areas described in Section 2.5.

Three articles reported rabies virus as the delivery of a substance to the brain, i.e., a neuronal tracer, and a vector [20-22]. This shows that research on rabies may contribute to neuroscience research.

\section{Trends in technology development related to rabies control based on patent applications}

Subsequently, we performed quantitative and qualitative analyzes of patent applications related to rabies control, e.g., technologies related to vaccines, screening, and the diagnosis of rabies.

\subsection{Method of analysis}

The survey of patent applications comprised the following four steps. 


\begin{tabular}{|c|c|c|c|c|c|c|}
\hline Rank & $\begin{array}{l}\text { Cited } \\
\text { number }\end{array}$ & Title & Author(s) & Journal & Volume, Page, Year & $\begin{array}{l}\text { Contribution to rabies } \\
\text { control }\end{array}$ \\
\hline 1 & 400 & $\begin{array}{l}\text { Pattern-oriented modeling of agent-based } \\
\text { complex systems: Lessons from ecology }\end{array}$ & $\begin{array}{l}\text { Grimm, V. } \\
\text { et al., }\end{array}$ & SCIENCE & $310,987-991,2005$ & $\begin{array}{l}\text { Yes (rabies prevalence } \\
\text { simulation) }\end{array}$ \\
\hline 2 & 377 & $\begin{array}{l}\text { Transvascular delivery of small interfering } \\
\text { RNA to the central nervous system }\end{array}$ & Kumar, P. et al., & NATURE & $448,39-43,2007$ & $\begin{array}{l}\text { No (usage of viral peptide } \\
\text { as delivery to the brain) }\end{array}$ \\
\hline$\sqrt{3}$ & 339 & $\begin{array}{l}\text { Cerebellar loops with motor cortex and } \\
\text { prefrontal cortex of a nonhuman primate }\end{array}$ & Kelly, R.M. et al., & $\begin{array}{l}\text { JOURNAL OF } \\
\text { NEUROSCIENCE }\end{array}$ & $23,8432-8444,2003$ & $\begin{array}{l}\text { No (usage of virus as } \\
\text { neuronal tracer) }\end{array}$ \\
\hline 4 & 314 & $\begin{array}{l}\text { Efficacy of RTS,S/ASO2 malaria vaccine } \\
\text { against Plasmodium falciparum infection in } \\
\text { semi-immune adult men in The Gambia: a } \\
\text { randomised trial }\end{array}$ & Bojang, K.A. et al., & LANCET & $358,1927-1934,2001$ & $\begin{array}{l}\text { No (usage of rabies vaccine } \\
\text { as a control of malaria } \\
\text { vaccine) }\end{array}$ \\
\hline 5 & 288 & $\begin{array}{l}\text { Re-evaluating the burden of rabies in Africa } \\
\text { and Asia }\end{array}$ & Knobel, D.L. et al., & $\begin{array}{l}\text { BULLETIN OF THE } \\
\text { WORLD HEALTH } \\
\text { ORGANIZATION }\end{array}$ & $83,360-368,2005$ & $\begin{array}{l}\text { Yes (study to quantify } \\
\text { public health and economic } \\
\text { burden) }\end{array}$ \\
\hline 6 & 261 & Small world effect in an epidemiological mode & Kuperman, M. et al., & $\begin{array}{l}\text { PHYSICAL REVIEW } \\
\text { LETTERS }\end{array}$ & $86,2909-2912,2001$ & $\begin{array}{l}\text { No (epidemiological model } \\
\text { based on the structure of a } \\
\text { population) }\end{array}$ \\
\hline$\overline{7}$ & 249 & $\begin{array}{l}\text { Cannabinoid-based drugs as anti- } \\
\text { inflammatory therapeutics }\end{array}$ & Klein, T.W. & $\begin{array}{l}\text { NATURE REVIEWS } \\
\text { IMMUNOLOGY }\end{array}$ & $5,400-411,2005$ & $\begin{array}{l}\text { No (therapeutic usefulness } \\
\text { of these drugs in chronic } \\
\text { inflammatory diseases) }\end{array}$ \\
\hline 8 & 239 & $\begin{array}{l}\text { Diseases of humans and their domestic } \\
\text { mammals: pathogen characteristics, host range } \\
\text { and the risk of emergence }\end{array}$ & Cleaveland, S. et al., & $\begin{array}{l}\text { PHILOSOPHICAL } \\
\text { TRANSACTIONS OF } \\
\text { THE ROYAL SOCIETY } \\
\text { OF LONDON SERIES } \\
\text { B-BIOLOGICAL } \\
\text { SCIENCES }\end{array}$ & $356,991-999,2001$ & $\begin{array}{l}\text { Indirectly yes (database } \\
\text { analysis of multihost } \\
\text { pathogens) }\end{array}$ \\
\hline 9 & 214 & $\begin{array}{l}\text { Rabies virus glycoprotein pseudotyping of } \\
\text { lentiviral vectors enables retrograde axonal } \\
\text { transport and access to the nervous system } \\
\text { after peripheral delivery }\end{array}$ & Mazarakis, N,D. et al., & $\begin{array}{l}\text { HUMAN } \\
\text { MOLECULAR } \\
\text { GENETICS }\end{array}$ & 10, 2109-2121, 2001 & $\begin{array}{l}\text { No (usage of virus protein } \\
\text { as a virus vector) }\end{array}$ \\
\hline 10 & 208 & Population biology of multihost pathogens & $\begin{array}{l}\text { Woolhouse, M.E.J. } \\
\text { et al., }\end{array}$ & SCIENCE & 292, 1109-1112, 2001 & $\begin{array}{l}\text { Indirectly yes (database } \\
\text { analysis of multihost } \\
\text { pathogens) }\end{array}$ \\
\hline
\end{tabular}

Table 2. Top 10 cited articles related to rabies during 2001-2011

\subsubsection{Step 1-Collection of data sources for patent applications}

The Derwent Patent Index ${ }^{\circledR}$ (DWPI) and the Derwent Patent Citation Index ${ }^{\circledR}$ (DPCI) $[23,24]$ were used to survey patent applications related to rabies control using the search strategy described below.

DWPI is one of the largest and most user-friendly patent databases in the world, which contains over 21.85 million patent families that cover over 45.2 million patent documents. It includes coverage of over 47 worldwide patent authorities with enhanced patent titles and abstracts prepared by subject experts to facilitate the survey of patent documents. Additionally the DWPI assembles all of the patent documents relating to an invention into a single database record as a "patent family". A single "patent family" is a set of either patent applications or publications taken in multiple countries to protect a single invention by a common inventor(s) [25]. DPCI provides patent citation information from 10 organizations, including the EPO and the WIPO.

To survey the number of applicants by nationality, we used the FAMPAT ${ }^{\circledR}$ [26], which is a comprehensive worldwide patent family database. We used the FAMPAT ${ }^{\circledR}$ because the DWPI does not include the nationalities of applicants. 


\subsubsection{Step 2-Screening and selection of patent applications}

Using the DWPI, we surveyed Asian, US, and European patent applications related to rabies control by patent family, as well as patent applications filed under the International Patent Cooperation Treaty [27] for 2001-2011 (the year when priority was claimed based on the patent application) on December 21, 2012. In this study, one should note that the data of "patent applications" represented the data of "patent families" assembled uniquely by the DWPI. The countries targeted for analysis are shown in Table 3 and they were selected based on our previous study, i.e., the countries that published more infectious disease research articles than other countries [10].

We screened patent applications using search formulae 1-7 as shown in Table 3, which were based on keywords and the IPC. Patent applications were selected that contained the keywords in the titles or abstracts and that belonged to the IPC categories. To ensure the complete capture of all relevant patent applications, we used "Rabies" and inflected forms of the keywords such as "Rabic" and "Rabid", and "Lyssa." We also used the IPC categories that included antigens, antibodies, amino acids, chemical compounds, and anti-infectives related to the Rhabdoviridae family or RNA viruses, which include the rabies virus and lyssaviruses.

After screening the patent applications, we selected patent applications related to rabies control. We reviewed all the abstracts and claims for patent applications to identify applications related to the prevention and diagnosis of rabies.

We primarily focused on patent applications that claimed technologies for preventive and diagnostic uses related to rabies genes and proteins, but we also included applications related to technologies for producing vaccine adjuvants and for stabilization, as well as other pertinent items within the search scope. For example, a patent application was included that claimed a recombinant adenovirus as a rabies vaccine carrier. However, we excluded patent applications related to research and therapeutic tools for other diseases, e.g., the synthesis of rabies virus proteins for human neurodegenerative disorder therapy and the development of a rabies virus vector for expressing other viral proteins.

\subsubsection{Step 3-Analysis of patent applications}

The patent applications selected in Step 2 were analyzed with respect to the following items; patenting activity (the number of patent applications per application year and for each country, and the number of applicants by nationality), major technical areas of patent applications, and the most cited patent applications. We used citation analysis as an indicator of important technological progress, upon which many later patents may rely [28].

\subsection{Total number of patent applications}

The screening of patent applications related to rabies control retrieved 354 candidates. The candidates included keywords related to rabies in the titles or abstracts and belonged to the IPC categories A61K-039/205, C07K-014/145, A61P-031/12, A61P-031/14, or G01N-033/569 (Table 3). Subsequently, we selected 237 of 354 patent applications by reviewing all the 


\begin{tabular}{|c|c|c|c|}
\hline & Search formula & $\begin{array}{l}\text { Number of } \\
\text { patent } \\
\text { applications } \\
\text { retrieved* }\end{array}$ & Survey content \\
\hline 1 & PRD = 2001:2011 & $11,315,347$ & Priority year \\
\hline 2 & $\begin{array}{l}\text { (US OR EP OR GB OR DE OR ES OR } \\
\text { FR OR IT OR NL OR JP OR CN OR KR } \\
\text { OR IN)/PC }\end{array}$ & $20,081,126$ & $\begin{array}{l}\text { Country or patent administration office (the US, the } \\
\text { European Patent Office, the UK, Germany, Spain, } \\
\text { France, Italy, the Netherlands, Japan, China, Korea, and } \\
\text { India) }\end{array}$ \\
\hline 3 & $\begin{array}{l}\text { (RABIES OR RABIC OR RABID OR } \\
\text { LYSSA)/TI/AB/EAB }\end{array}$ & 1,317 & Keywords related to rabies \\
\hline 4 & $\begin{array}{l}\text { (A61K-039/205 OR } \\
\text { C07K-014/145)/IC }\end{array}$ & 601 & $\begin{array}{l}\text { IPC for medical preparations containing antigens or } \\
\text { antibodies against Rhabdoviridae (A61K-039/205) or } \\
\text { peptides with more than } 20 \text { amino acids from } \\
\text { Rhabdoviridae (C07K-014/145) }\end{array}$ \\
\hline 5 & (A61P-031/12 OR A61P-031/14)/IC & 25,706 & $\begin{array}{l}\text { IPC for the specific therapeutic activity of chemical } \\
\text { compounds or medicinal preparations for } \\
\text { antiinfectives (A61P-031/12) or RNA viruses } \\
\text { (A61P-031/14) }\end{array}$ \\
\hline 6 & $(\mathrm{G} 01 \mathrm{~N}-033 / 569) / \mathrm{IC}$ & 11,177 & $\begin{array}{l}\text { IPC for investigating or analyzing materials by } \\
\text { determining the chemical or physical properties of } \\
\text { micro-organisms }\end{array}$ \\
\hline 7 & $\begin{array}{l}1 \text { AND } 2 \text { AND } 3 \text { AND } \\
(4 \text { OR } 5 \text { OR } 6)\end{array}$ & 354 & Targeted patent applications \\
\hline
\end{tabular}

*The number of patent applications was calculated by patent family. In some cases, a patent family contains a number of relevant patent applications.

Table 3. Table 3 Search formula and the number of patent applications retrieved

abstracts and claims to identify patent applications related to rabies control. The following analysis was based on results, which included 237 patent applications.

\subsection{Annual change in the number of patent applications by country}

We regrouped the patent applications and applicants for each country to identify possible differences in technology development among various countries. The numbers of PCT applications and applications in each country were stable during 2001-2011, except in China where the number increased relatively. The US had the most patent applications until 2007, but was overtaken by China in 2008. We found that China had a remarkable increase in patent 
applications after 2002. Japan had a downward trend after 2009 and fell behind India during 2009-2010 (Figure 5).

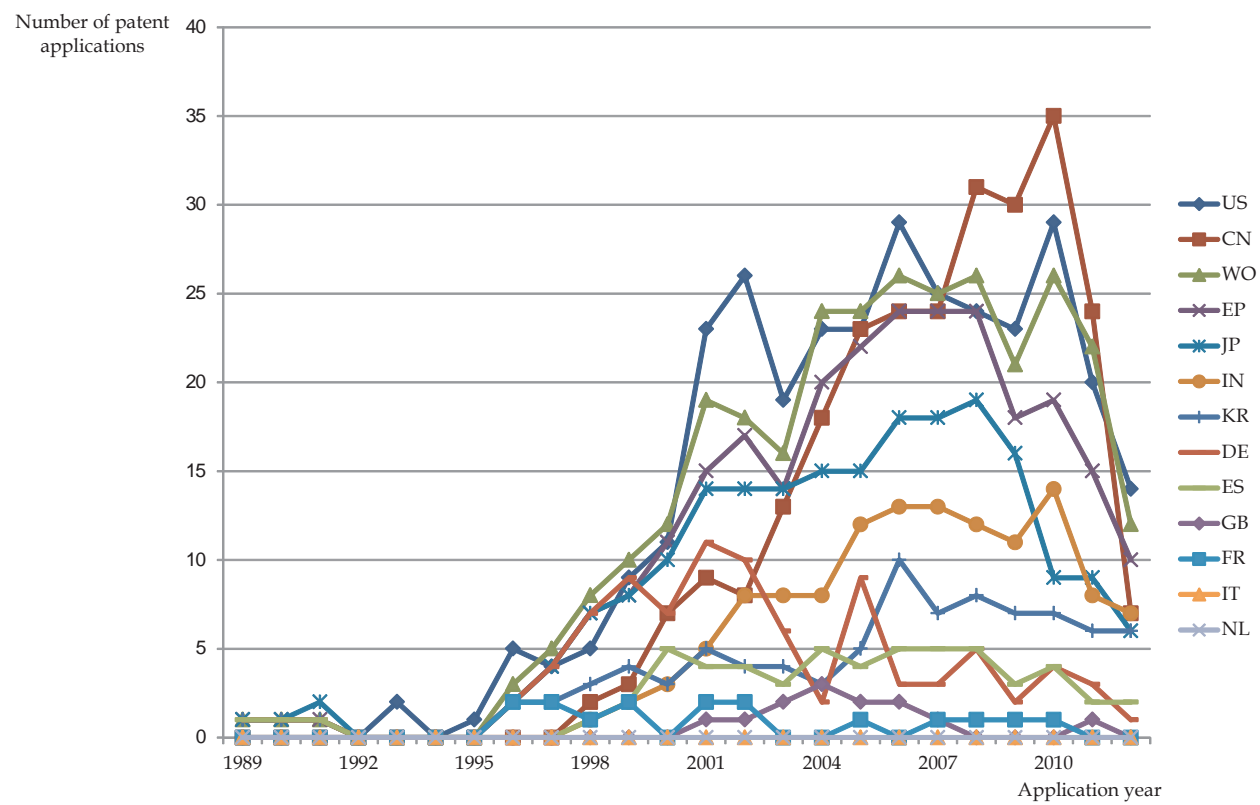

Figure 5. Number of patent applications related to rabies control by country during 2001-2011

The number of patent applications was calculated by patent family. In some cases, a patent family contains a number of relevant patent applications. US: United States, CN: China, WO: PCT, EP: European Patent Office, JP: Japan, IN: India, KR: Korea, DE: Germany, ES: Spain, GB: UK, FR: France, IT: Italy, NL: the Netherlands

\subsection{Number of patent applicants by country}

The US had the most applicants, but was overtaken by China in 2008-2009. China had a remarkable increase in applicants after 2003, while it decreased temporarily in 2006. Germany, Japan, and France had $\leq 5$ patent applications per year during 2001-2011 (Figure 6).

\subsection{Major technological fields of patent applications}

The technological types of 237 patent applications related to rabies control were determined in the contexts of prevention, diagnosis, and treatment. As shown in Table 4, the patent applications were classified into seven technological fields: recombinant virus, protein, peptide, organic active ingredient, natural product, fabrication method, and mutant. Patent applications related to recombinant viruses were the most frequent and they primarily claimed 


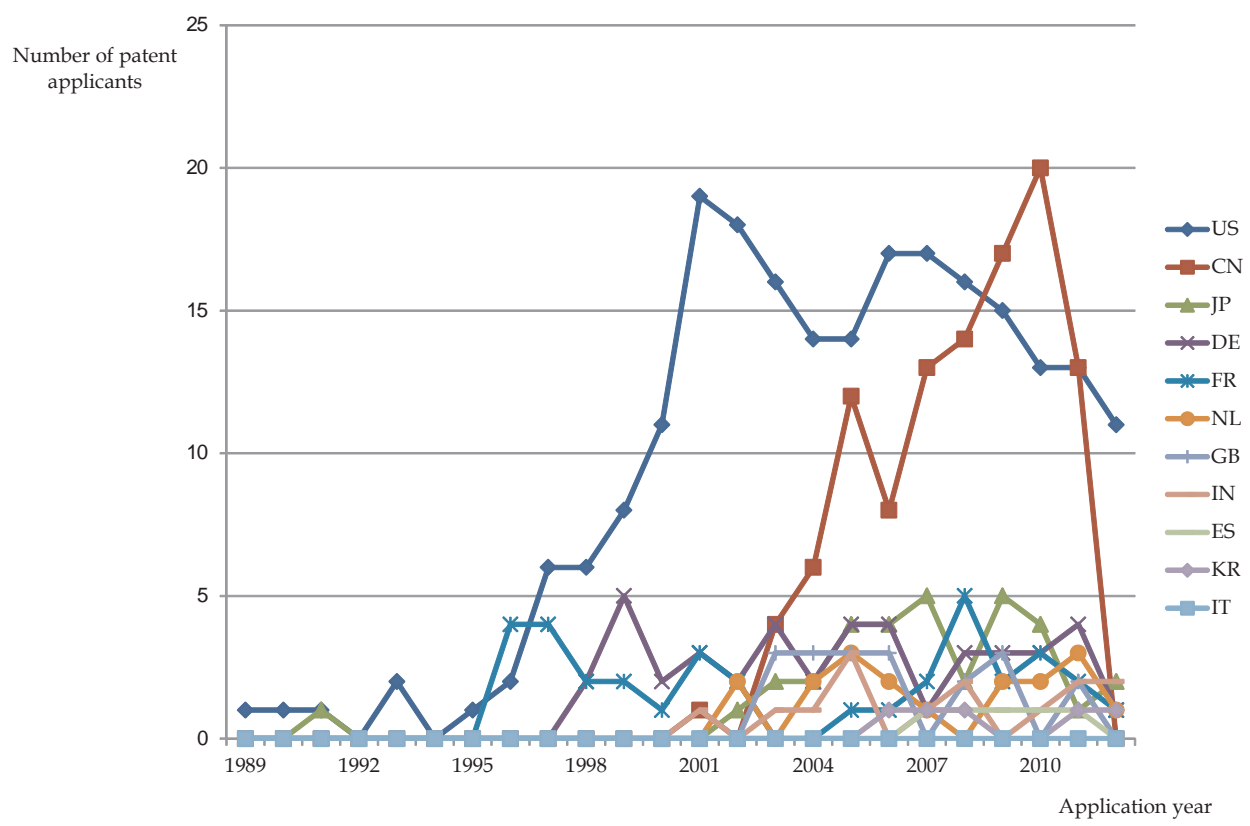

US: United States, CN: China, JP: Japan, DE: Germany, FR: France, NL: the Netherlands, GB: UK, IN: India, ES: Spain, KR: Korea, IT: Italy

Figure 6. Number of patent applicants related to rabies control by country during 2001-2011

uses for the prevention and treatment of rabies. Patent applications related to organic active ingredients used for treatments, fabrication methods for prevention (primarily vaccines), and natural products and Chinese herbal extracts for treatment were more frequent than other patent applications. Patent applications related to natural products and Chinese herbal extracts were primarily from China.

The number of patent applications was calculated by patent family. In some cases, a patent belonged to two or more technology fields, so the total number of applications exceeded 237.

\subsection{Top 10 most cited patent applications}

Table 5 shows the top 10 most cited patent applications related to rabies. All the patent applications were related to diagnostic or therapeutic methods for rabies, such as immunoconjugates (US 5332567, WO200454622), a vaccine carrier (US 6019978), and a monoclonal antibody production system (WO200476677). It was interesting that all the patent applications were applicable to various pathogens, such as bacteria, viruses, and mycoplasma, whereas none were specifically applicable to the rabies virus. 


\begin{tabular}{|l|l|l|l|l|}
\hline & $\begin{array}{l}\text { Prevention } \\
\text { (primarily } \\
\text { vaccine) }\end{array}$ & $\begin{array}{l}\text { Diagnosis } \\
\text { (detection of } \\
\text { virus, } \\
\text { antibodies) }\end{array}$ & $\begin{array}{l}\text { Treatment } \\
\text { (medical drugs } \\
\text { for post-exposure } \\
\text { prophylaxis etc.) }\end{array}$ & Other \\
\hline $\begin{array}{l}\text { Recombinant virus } \\
\text { (e.g. replication-defective adenovirus } \\
\text { recombinant as a rabies vaccine carrier) }\end{array}$ & 60 & 12 & 42 & 9 \\
\hline $\begin{array}{l}\text { Protein (e.g. chimeric rabies G protein ) } \\
\text { Peptide (e.g. antigenic peptide of rabies virus) }\end{array}$ & 18 & 13 & 15 & 0 \\
\hline $\begin{array}{l}\text { Organic active ingredient (e.g. } \\
\text { organophosphorous compound for producing } \\
\text { medicaments for therapeutic treatment of } \\
\text { infections caused by virus ) }\end{array}$ & 17 & 8 & 14 & 0 \\
\hline $\begin{array}{l}\text { Natural product, Chinese herbal extract (e.g. } \\
\text { red bean-derived antiviral agent) }\end{array}$ & 9 & 2 & 36 & 0 \\
\hline $\begin{array}{l}\text { Fabrication method (e.g. preparation method of } \\
\text { rabies vaccine) }\end{array}$ & 31 & 0 & 24 & 2 \\
\hline $\begin{array}{l}\text { Mutant (e.g. attenuated recombinant rabies } \\
\text { virus mutant for live vaccines) }\end{array}$ & 10 & 7 & 15 & 8 \\
\hline \begin{tabular}{l} 
Other \\
\hline
\end{tabular} & 10 & 1 & 5 & 0 \\
\hline & & 14 & 5 & 2 \\
\hline
\end{tabular}

Table 4. Technology fields of patent applications related to rabies control during 2001-2011

\begin{tabular}{|c|c|c|c|c|c|}
\hline Rank & $\begin{array}{l}\text { Cited } \\
\text { number }\end{array}$ & patent number & applicants & Tifle & Contribution to rabies control \\
\hline 1 & 101 & US5332567 & IMMUNOMEDICS & $\begin{array}{l}\text { Detection and treatment of infections with } \\
\text { immunoconjugates }\end{array}$ & $\begin{array}{l}\text { Yes (method of targeting a polyspecific diagnostic agent } \\
\text { for virus infection including rabies) }\end{array}$ \\
\hline 2 & 57 & WO200366005 & $\begin{array}{l}\text { CONFORMA } \\
\text { THERAPEUTICS }\end{array}$ & $\begin{array}{l}\text { Ansamycins having improved pharmacological and } \\
\text { biological properties }\end{array}$ & $\begin{array}{l}\text { Yes (method of treating or preventing infection } \\
\text { including rabies) }\end{array}$ \\
\hline$\overline{3}$ & 45 & WO200464759 & CHIRON & Use of tryptanthrin compounds for immune potentiation & $\begin{array}{l}\text { Yes (enhancement of the immune response to infections } \\
\text { including rabies) }\end{array}$ \\
\hline 4 & 40 & WO200476677 & $\begin{array}{l}\text { INSTITUTE FOR } \\
\text { RESEARCH } \\
\text { BIOMEDICINE }\end{array}$ & $\begin{array}{l}\text { Monoclonal antibody production by EBV transformation } \\
\text { of B cells }\end{array}$ & $\begin{array}{l}\text { Yes (providing a neutralizing monoclonal human } \\
\text { antibodies that recognizes antigens from various } \\
\text { pathogens including rabies virus) }\end{array}$ \\
\hline 5 & 37 & US20060228300 & $\begin{array}{l}\text { IBC } \\
\text { PHARMACEUTICALS }\end{array}$ & $\begin{array}{l}\text { Stably tethered structures of defined compositions with } \\
\text { multiple functions or binding specificities }\end{array}$ & $\begin{array}{l}\text { Yes (useful for treating subjects infected with various } \\
\text { pathogens including rabies virus) }\end{array}$ \\
\hline 6 & 32 & US6019978 & $\begin{array}{l}\text { WISTAR INSTITUTE } \\
\text { OF ANATOMY \& } \\
\text { BIOLOGY } \\
\text { UNIVERSITY OF } \\
\text { PENNSYLVANIA }\end{array}$ & $\begin{array}{l}\text { Replication-defective adenovirus human type } 5 \\
\text { recombinant as a vaccine carrier }\end{array}$ & $\begin{array}{l}\text { Yes (more efficacious method in comparison with the } \\
\text { currently used vaccinia rabies vaccine) }\end{array}$ \\
\hline 7 & 31 & WO9800166 & RHONE MERIEUX & $\begin{array}{l}\text { Recombinant canine adenovirus (CAV) containing } \\
\text { exogenous DNA }\end{array}$ & $\begin{array}{l}\text { Yes (vector for cloning heterologous DNA encodes } \\
\text { epitopes of interests from antigens of veterinary } \\
\text { pathogens including rabies) }\end{array}$ \\
\hline 8 & 31 & US6180111 & $\begin{array}{l}\text { MARYLAND } \\
\text { UNIVERSITY OF }\end{array}$ & Vaccine delivery system & $\begin{array}{l}\text { Yes (useful for the diagnosis of viral diseases including } \\
\text { rabies) }\end{array}$ \\
\hline 9 & 29 & WO200775270 & $\begin{array}{l}\text { IBC } \\
\text { PHARMACEUTICALS }\end{array}$ & Multivalent immunoglobulin-based bioactive assemblies & $\begin{array}{l}\text { Yes (useful for treating infection with various } \\
\text { pathogens including rabies virus) }\end{array}$ \\
\hline 10 & 29 & WO200454622 & $\begin{array}{l}\text { IMMUNOMEDICS } \\
\text { MCCALL JOHN } \\
\text { DOUGLAS }\end{array}$ & $\begin{array}{l}\text { Immunoconjugates with an intracellularly-cleavable } \\
\text { linkage }\end{array}$ & $\begin{array}{l}\text { Yes (useful for therapeutic conjugates against } \\
\text { pathogens including rabies virus) }\end{array}$ \\
\hline
\end{tabular}

Table 5. Top 10 most cited patent applications related to rabies control during 2001-2011 


\section{General overview of research and technology development related to rabies control based on bibliometric and patent analyses}

Our bibliometric and patent analyses using the Web of Science ${ }^{\circledR}$, DWPI, and DPCI highlighted five main features of the trends in research and technology development related to rabies control during 2001-2011.

\subsection{Research and technology developments related to rabies control were diverse and polyspecific}

Given that the major research areas were veterinary sciences, virology, and immunology (Figure 4), and that the two most cited articles related to rabies control belonged to interdisciplinary research regions, i.e., agent-based modeling and economic analysis (Table 2), it is apparent that rabies research has diversified from classical to novel research areas. In particular, new research is prospective and aims to accelerate the development of domestic and international management frameworks for rabies.

However, the methods used for rabies diagnosis and vaccine development are progressing if we take patent US 5332567 and US 6019978 as examples of the top 10 most cited patent applications (Table 5). These methods were characterized as being applicable to various other pathogens and were polyspecific. Given that current rabies vaccines aim to introduce new functions, e.g., animal rabies vaccines combined with other antigens [3], these polyspecific methods would contribute to further vaccine development.

\subsection{Gap between research and technology development for rabies control}

We found that the number of articles related to rabies increased throughout the world, but the number of patent applications directed at rabies control was stable according to PCT and in each country. Given that only two of the top 10 most cited articles were directly related to rabies control, as shown in Table 2, and that none of the top 10 patent applications were specifically for rabies control, as shown in Table 5, it was not clear whether the articles were directly linked to the patent applications for rabies. Thus, it is not necessarily that research on rabies leads to technological developments related to rabies control.

\subsection{The US, France, and the UK are the leading countries for rabies research}

The survey demonstrated that the US led rabies research because it had the highest percentage of total articles related to rabies, i.e., $32.5 \%$ of the total. France ranked second (10.6\%) but there was a big difference compared with the US. These two countries and the UK were also the top three producers of articles in the area of infectious diseases (Table 1). Four of the top five organizations that published articles related to rabies were also in these three countries. These results showed that the US, France, and the UK were the undisputed leaders in research on rabies and all infectious diseases. 


\subsection{Brazil was a particularly productive country for rabies research}

Like the US, France, and the UK, Brazil was considered to be a productive country for rabies research because it published the fourth highest number of articles (Table 1). The Universidade de Sao Paulo was ranked fourth among the top five organizations (Figure 3) and it played a leading role in rabies research in Brazil.

Brazil may have a high level of rabies research because this country has initiated nationwide public campaigns to vaccinate dogs and cats against rabies, which have demanded studies to assess the antibody levels in vaccinated animals [29]. Moreover, research on rabies control has been active because the population has a serious risk of infection given the close relationships between these potential zoonosis-transmitting animals and humans [29].

\subsection{Development of patent applications for rabies control in China}

China exhibited a remarkable increase in patent applications (Figure 5). It was significant that China overtook the US with respect to the number of patent applications after 2007. From a technological perspective, patent applications related to natural products and Chinese herbal extracts increased greatly, as described in section 3.5.

The Chinese statistics showed that 1,633,000 patent applications (the total number of invention patents, design patents, and utility models) were filed with the State Intellectual Property Office (SIPO) by 2011, with a greater than threefold increase during 2005 alone [30]. This remarkable increase in the overall volume of patent applications in China may be attributable to the subsidization policy specified by the China Elements of Strategy for Intellectural Property Right, which facilitated the creation, application, protection, and management of intellectual property rights in 2008. Thus, the notable increase in overall patent applications after the change in China's policy may have led to the increased number of patent applications related to rabies control.

\section{Conclusion}

This chapter describes the trends in research and technology development related to rabies control during 2001-2011, which illustrate the measures introduced to control zoonoses. We found that the research and technology development activities differed among countries, which were characterized as diverse and polyspecific. The methods used for rabies diagnosis and vaccine development were found to be progressing.

The highly cited research on agent-based modeling and economic impact analysis shows that new interdisciplinary studies of rabies are being conducted. These studies are aimed to accelerate the development of domestic and international management frameworks for rabies.

This bibliometric and patent analysis did not demonstrate that articles (indicators of research outputs) were closely linked to patent applications (indicators of technology development). Our method aimed to measure science linkage to analyze the effects of science and research 
on technology development. Science linkage is an indicator of technological innovation, which is based on calculating the number of non-patent references such as articles, which are an indicator of the degree of science related to patents, i.e., the number of articles cited per patent [31]. There are technological limitations to science linkage, but many studies have aimed to measure the linkage of patents filed in the US and Europe [31]. From this perspective, measuring science linkage may be a challenge during future surveys of the trends in research and technology development related to rabies control. This challenge will also apply to zoonoses in general.

\section{Acknowledgements}

The study described in this chapter was supported by a Japanese Grant-in-Aid for Scientific Research (KAKENHI) (research project number 23580435). We thank Mr. Mitsuaki Baba (Property Co., Ltd.) for his technical support to survey patents.

\section{Author details}

Hiromi Takahashi-Omoe $^{1^{*}}$ and Katsuhiko Omoe ${ }^{2}$

*Address all correspondence to: omoe@nistep.go.jp

1 National Institute of Science and Technology Policy (NISTEP), Japan

2 Iwate University, Japan

\section{References}

[1] Jones KE, Patel NG, Levy MA, Storeygard A, Balk D, Gittleman JL, Daszak P. Global trends in emerging infectious diseases. Nature 2008; 451 990-994.

[2] Lembo T, Hampson K, Kaare MT, Ernest E, Knobel D, Kazwala RR, Haydon DT, Cleaveland S. The feasibility of canine rabies eliminations in Africa: Dispelling doubts with data. PLOS Neglected Tropical Diseases 2010; 4 e626. http:// www.plosntds.org/article/info\%3Adoi\%2F10.1371\%2Fjournal.pntd.0000626 (accessed 15 August 2013)

[3] Tordo N. New developments in rabies vaccines. OIE Global Conference on Rabies Control, 7-9 September 2011, Seoul, Republic of Korea. http://www.oie.int/eng/ A_RABIES/Abstracts_rabiesConf/abstract1-6/S2/Tordo.pdf (accessed 15 August 2013) 
[4] Nishizono A, Khawplod P, Ahmed K, Goto K, Shiota S, Mifune K, Yasui T, Takayama K, Kobayashi Y, Mannen K, Tepsumethanon V, Mitmoonpitak C, Inoue S, Morimoto K. A simple and rapid immunochromatographic test kit for rabies diagnosis. Microbiology and Immunology 2008; 52 243-249.

[5] Xu G, Weber P, Hu Q, Xue H, Audry L, Li C, Wu J, Bourhy H. WELYSSA: a simple tool using mouse monoclonal antibodies for the detection of lyssavirus nucleocapsid in rabies suspecyed speciments. Developments in biologicals 2008; 131 555-561.

[6] Falagas ME, Bliziotis IA, Kondilis B, Soteriades ES. Eighteen years of research on AIDS: contribution of and collaborations between different world regions. AIDS Research and Human Retroviruses 2006; 22 1199-1205.

[7] Arunachalam S, Gunasekaran S. Tuberculosis research in India and China: From bibliometrics to research policy. Current Science 2002, 82 933-947.

[8] Bliziotis IA, Paraschakis K, Vergidis PI, Karavasiou AI, Falagas ME. Worldwide trends in quantity and quality of published articles in the field of infectious diseases. BMC Infectious Diseases 2005; 5 16. http://www.biomedcentral.com/1471-2334/5/16 (accessed 15 August 2013)

[9] Takahashi-Omoe H, Omoe K, Okabe N. New journal selection for quantitative survey of infectious disease research: application for Asian trend analysis. BMC Medical Research Methodology 2009; 9 67. http://www.biomedcentral.com/1471-2288/9/67 (accessed 15 August 2013)

[10] Takahashi-Omoe H, Omoe K. Worldwide trends in infectious disease research revealed by a new bibliometric method. Rijeka, In Tech; 2012. http://www.intechopen.com/books/insight-and-control-of-infectious-disease-in-global-scenario/ worldwide-trends-in-infectious-disease-research-revealed-by-bibliometrics (accessed 15 August 2013)

[11] Ernst, H. Patent information for strategic technology management. World Patent Information 2003; 25 233-242.

[12] Organizsation for Economic Co-operation and Development. Patent statistics manual.

[13] http://www.oecd.org/science/innovationinsciencetechnologyandindustry/oecdpatentstatisticsmanual.htm (accessed 15 August 2013)

[14] Sanyal G, Shi L. A review of multiple approaches towards an improved hepatitis B vaccine. Expert Opinion on Therapeutic Patents 2009; 19 59-72.

[15] World Intellectual Property Organization. WIPO patent search report on pandemic influenza preparedness (PIP)-related patents and patent applications. WIPO; 2011. http://www.wipo.int/export/sites/www/patentscope/en/programs/patent_landscapes/documents/patent_landscapes/influenza_full_report_01_04_2011.pdf （accessed 15 August 2013) 
[16] Dou H, Bai Y.. A rapid analysis of avian influenza patens in the Esp@cenet database R\&D strategies and country comparisons. World Patent Information 2007; 29 26-32.

[17] Wang SJ. Candida vaccines development from point view of US patent application. Human Vaccines 2011,7 1165-1171.

[18] Thomson Reuters. Web of Science. http://thomsonreuters.com/web-of-science/ (accessed 15 August 2013)

[19] Grimm V, Revilla E, Berger U, Jeltsch F, Mooij WM, Railsback SF, Thulke HH, Weiner J, Wiegand T, DeAngelis DL. Pattern-oriented modeling of agent-based complex systems: Lessons from ecology. Science 2005; 310 987-991.

[20] Knobel DL, Cleaveland S, Coleman PG, Fèvre EM, Meltzer MI, Miranda ME, Shaw A, Zinsstag J, Meslin FX. Re-evaluating the burden of rabies in Africa and Asia. Bulletin of the World Health Organization 2005; 83 360-368.

[21] Mazarakis ND, Azzouz M, Rohll JB, Ellard FM, Wilkes FJ, Olsen AL, Carter EE, Barber RD, Baban, DF, Kingsman SM, Kingsman AJ, O'Malley K, Mitrophanous KA. Rabies virus glycoprotein pseudotyping of lentiviral vectors enables retrograde axonal transport and access to the nervous system after peripheral delivery. Human Molecular Genetics 2001; 10 2109-2121.

[22] Kelly RM, Strick PL. Cerebellar loops with motor cortex and prefrontal cortex of a nonhuman primate. Journal of Neuroscience 2003; 23 8432-8444.

[23] Kumar P, Wu H, McBride JL, Jung KE, Kim MH, Davidson BL, Lee SK, Shankar P, Manjunath N. Transvascular delivery of samll interfering RNA to the central nervous system. Nature 2007; 448 39-43.

[24] Thomson Reuters. Derwent World Patents Index. http:/thomsonreuters.com/ derwent-world-patents-index/ (accessed 15 August 2013)

[25] Thomson Reuters. Patent Citation Index. http:// http://ip-science.thomsonreuters.com/support/patents/userguides/pciguides/ (accessed 15 August 2013)

[26] Questel. FamPat-The invention at the heart of family. http://www.questel.orbit.com/ prodsandservices/FamPat.htm (accessed 15 August 2013)

[27] World Intellectual Property Organization. PCT. The International Patent System. http://www.wipo.int/pct/en/ (accessed 15 August 2013)

[28] Smith VM. Who's who in additives-a technological approach. Chemical Week 1993; 38 137-142.

[29] Albas A, Picolo MR, Soares CN, Bachega HV, Tarumoto MH. Humoral immune response in dogs and cats vaccinated against rabies in southeastern Brazil. Journal of Venomous Animals and Toxins including Tropical Diseases 2013;19 17. 
[30] Nishiuchi, S. Analysis of the trend on intellectual property in China. http://monoist.atmarkit.co.jp/mn/articles/1207/23/news009.html (accessed 15 August 2013)

[31] Tamada S. Measureing science linkage in four priority technology categories. Research \& Review, Research Institute of Economy, Trade \& Industry, IAA; 2004. http:// www.rieti.go.jp/en/papers/research-review/020.html (accessed 15 August 2013) 